\title{
Case Report: A Rare Case of Intradural Spinal Cord Dermoid Cyst
}

\section{Georges Fares ${ }^{1 *}$, Nakhle Mhanna ${ }^{1 *}$, Monique Chammas ${ }^{2}$, Maroun Ghabach ${ }^{2}$ and Gilbert Moubarak ${ }^{1}$}

${ }^{1}$ Department of Orthopedic Surgery, Rosary Sisters Hospital, Lebanon

${ }^{2}$ Department of anesthesia, Rosary Sisters Hospital, Lebanon

Submission: June 19, 2018; Published: July 03, 2018

*Corresponding author: Georges Fares, PGY3 orthopedics resident, Lebanese University, Tel: 96170864696; Email: georges_fares1@hotmail.com

\section{Abstract}

Intradural dermoid cysts are exceptionally rare lesions with high morbidity rate. A surgical excision of these tumors is technically challenging with high risk of iatrogenic permanent lesions. However, it remains the only possible treatment in symptomatic patients. In this report, we present a case of a male patient with an intradural lesion just below the conus medullaris, extending from L3 to L5, that was treated surgically using the microscope to approach the intradural space.

\section{Introduction}

This is a case report of a patient suffering from intradural dermoid cyst diagnosed at our clinic. The objective of this report is to present the symptoms of such cases, describe the surgical treatment and to assess the patient's condition upon follow up. Other published papers have described different presentations of dermoid cyst with different treatments. Sharing these cases with the scientific community is very crucial to delineate the most proper approach to these patients.

\section{Case Report}

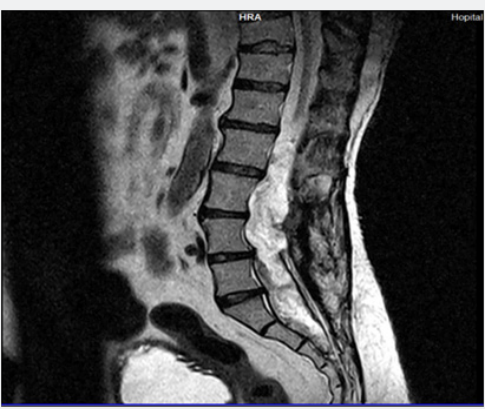

Figure 1: Hyperintense signal from L2 till S1 plus scalloping of lower lumbar vertebrae.

A 57-year-old man known to have hypertension, presented with three days history of urinary incontinence, back pain with increasing intensity, left thigh atrophy and left lower limb paralysis over the last 4 weeks. There is a history of lumbar surgery for back pain, urinary incontinence and weakness 36 years prior to his presentation to our clinic. Imaging at that time showed a cyst in the spinal cord which was excised. After the surgery his symptoms resolved completely until presenting to our clinic.Lumbar x-ray was done first and showed scalloping of the lumbar vertebrae. MRI was done next and it demonstrated a hyperintense intradural lesion on T2 weighted images that extended from L2 to S1(Figure 1).

Results

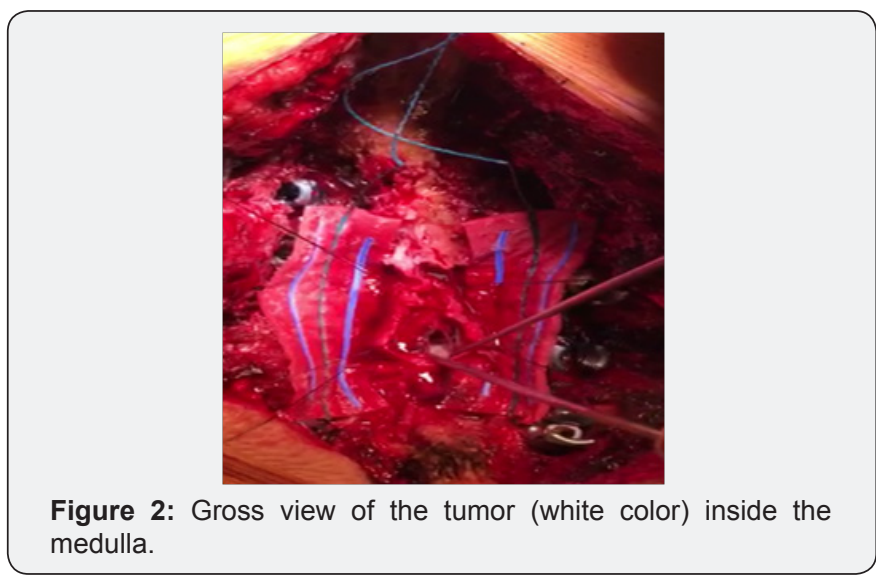

Surgery was performed. A previous laminectomy from L2 till L3 was discovered intraoperatively. The laminectomy was extended to L5. The midline myelotomy performed showed an avascular tumor with a thick wall inside the dura just distal to conus medullaris and pressing the spinal nerves to the periphery (Figure 2). Using the microscope, the tumor wall was incised, and a white semi fluid material was found (Figure 3). Extensive excision of the white material was removed with nerve preservation and partial excision of the tumor wall. 


\section{Orthopedics and Rheumatology Open Access Journal (OROAJ)}

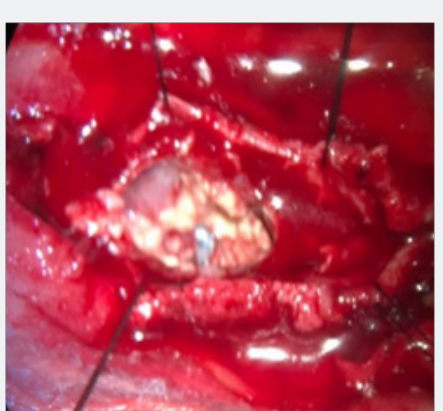

Figure 3: Tumor viewed under the microscope.

Two weeks post operatively, the pathology study showed that the tumor was a dermoid cyst (Figure 4). One month post operatively, the patient had moderate improvement in his bladder function with marked gain in power of his lower limbs. Two months later the patient was examined at the clinic and showed important improvement in his motor activity with considerable gain in muscle mass. He also reported partial recuperation in his urinary continence along with mild intermittent back pain relieved with pain killers. The patient regained his independence and returned to his work as a craftsman.

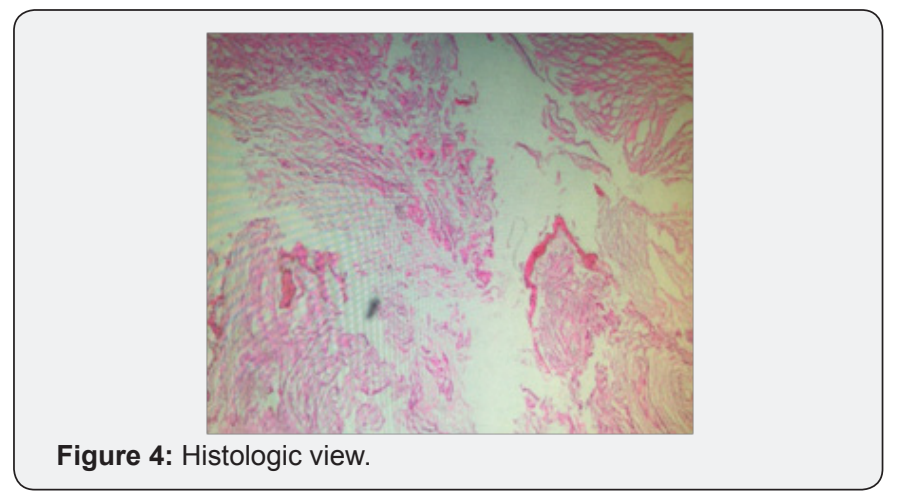

Discussion

Itramedullay dermoid cysts are very rare lesions; (0.8-2\% of all intraspinal tumors) with insidious presentation uncommonly seen in clinical practice [1]. The most common location is the lumbosacral spine in $60 \%$ of cases [2]. Most of the publications regarding these lesions are case reports [3]. The composition of these tumors consists of keratinized stratified squamous cell epithelium, cholesterol crystals, hair and sebaceous glands [3]. Many authors suggest that the origin of the dermoid cyst is an embryological deformation caused by inclusion of the ectodermal cells into the spinal canal during the 3rd to 5thweek of fetal life [4]. Others suggest it might be caused by iatrogenic introduction of skin cells into the subdural space, as in the case of lumbar puncture or spinal surgery [5]. Around half of the reported dermoid cysts are associated with dermal sinus which is due to the defect of separation of ectoderm from neural tube during the embryology phase $[6,7]$. The most common presentation is gradual onset of radicular pain, or an accumulation of several neurologic deficits over a long period of time due to the impingement of the neural elements by the tumor. These tumors reach large sizes before becoming symptomatic because of their slow growing nature [8].

It has been reported that some patients present suddenly with intractable pain or cauda equina symptoms. This is caused by the rupture of the tumor and spilling of its contents into the subarachnoid space [5]. This rupture can occur spontaneously, intraoperatively or post trauma and is associated with high morbidity rate [8]. The dermoid cysts associated with dermal sinus tend to be discovered early in life due to the recurrent meningitis or less commonly an intramedullary abscess [9].

MRI is the imaging modality of choice; it shows hyperintense signals onT1 images most commonly and sometimes on T2 images. Surgical excision remains the gold standard of treatment; it produces a rapid improvement post operatively and sometimes a gain in the preoperative deficit. These tumors have high rate of recurrence after months to years post-surgery. This predilection for recurrence is due to incomplete resection of the tumor at the time of surgery with remaining remnants of the stratified epithelium. The remnants are difficult to resect safely during surgery because of its adhesions to the surrounding tissues and the possible undesirable iatrogenic trauma on the spinal cord during resection. Suocheng et al. [10]in their review on 5 cases noted absence of cyst recurrence within 113 months of follow up after complete excision of the capsule [10]. Nevertheless, the majority surgeons still propose a safe conservative approach to avoid iatrogenic spinal injuries [11]. Some authors propose the implantation of Ommaya reservoir for continuous percutaneous drainage of the cyst contents especially in children to avoid repetitive surgeries [10]. Needless to say, that the decision to operate should be based solely on the symptoms and not on imaging results keeping in mind the necessity for repetitive MRIs post operatively to detect recurrences.

\section{Conclusion}

Dermoid cysts of the spine are rare benign tumors that should be followed conservatively upon incidental discovery and excised only when becoming symptomatic. Their presentation is usually gradual neurologic deficits due to compression of the nerves or acute because of the cyst rupture. Even with the advancement of microsurgical techniques it is still not advised to totally resect the tumor because of the high risk of a permanent neurologic deficit. It is important to inform the patient of the high possibility of recurrence. Ommaya reservoir in children for percutaneous drainage is advantageous.

\section{Conflict of Interest}

Authors of this paper declare there is neither financial interest nor conflict of interest in this case report.

\section{References}

1. Aoun SG, Liu MA, Still M, El Ahmadieh TY, Tamimi MA (2018) Dermoid cysts of the conus medullaris: Clinical review, case series and management strategies. J Clin Neurosci 50: 247-251. 
2. Graham DV, Tampieri D, Villemure JG (1988) Intramedullary dermoid tumor diagnosed with the assistance of magnetic resonance imaging Neurosurgery 23(6): 765-767.

3. Lee B, Jeelani Y, McComb JG (2013) Congenital dermal sinus with an infected dermoid cyst in the cervico-thoracic spinal cord. Pediatr Neurosurg 49(2): 89-92.

4. Netsky MG (1988) Epidermoid tumors. Review of the literature. Surg Neurol 29(6): 477-483.

5. De Maio PN, Mikulis DJ, Kiehl TR, Guha A (2012) AIRP best cases in radiologic-pathologic correlation: Spinal conus dermoid cyst with lipid dissemination. Radiographics 32(4): 1215-1221.

6. Cha JG, Paik SH, Park JS, Park SJ, Kim DH et al. (2006) Ruptured spinal dermoid cyst with disseminated intracranial fat droplets. Br J Radiol 79(938): 167-169.

This work is licensed under Creative Commons Attribution 4.0 License

DOI: 10.19080/OROAJ.2018.12.555834
7. Houx L, Brochard S, Peudenier S, Dam Hieu P and Rémy-Néris 0 (2011) Recovery after tetraplegia caused by dermal sinus infection: intramedullary abscess and tetraparesis. Pediatr Neurol 44(3): 229232 .

8. Altay H, Kitiș O, Calli C and Yünten N (2006) A spinal dermoid tumor that ruptured into the subarachnoidal space and syrinx cavity. Diagn Interv Radiol 12(4): 171-173.

9. Morandi X, Mercier P, Fournier HD, Brassier G (1999) Dermal sinus and intramedullary spinal cord abscess. Report of two cases and review of the literature. Childs Nerv Syst 15(4): 202-206.

10. Suocheng G, Yazhou X (2014) A review on five cases of intramedullary dermoid cyst. Childs Nerv Syst 30(4): 659-664.

11. Tekkök IH (2008) Intramedullary epidermoid cysts. J Neurosurg Spine 8(2): 202-203.

\section{Your next submission with Juniper Publishers} will reach you the below assets

- Quality Editorial service

- Swift Peer Review

- Reprints availability

- E-prints Service

- Manuscript Podcast for convenient understanding

- Global attainment for your research

- Manuscript accessibility in different formats

(Pdf, E-pub, Full Text, Audio)

- Unceasing customer service

Track the below URL for one-step submission https://juniperpublishers.com/online-submission.php 